\title{
PROPRIEDADES FUNCIONAIS (TECNOLÓGICAS) DA PAREDE CELULAR DE LEVEDURAS DA FERMENTAÇÃO ALCOÓLICA E DAS FRAÇÕES GLICANA, MANANA E GLICOPROTEINA ${ }^{1}$
}

\author{
Saula Goulart CHAUD ${ }^{2,3}$, Valdemiro Carlos SGARBIERI ${ }^{2, *}$
}

\begin{abstract}
RESUMO
Foram objetivos do presente trabalho o fracionamento, a caracterização química e o estudo das propriedades funcionais (tecnológicas) da fração parede celular (PC) de leveduras da fermentação alcóolica e das subfrações glicana, manana e glicoproteína. O fracionamento foi realizado por processos físico-químicos de extração, centrifugação e secagem em spray dryer, a caracterização química pela determinação da composição centesimal e as propriedades funcionais pelo uso de técnicas apropriadas. Os componentes predominantes da parede celular (PC) foram proteína (19\%) e fibra solúvel (74\%), da fração glicoproteina, foram as proteínas $(35,5 \%)$ e fibra solúvel (56\%), nas frações manana (M) e glicana solúvel (GS) predominaram as fibras solúveis ( 70\%) e na fração glicana insolúvel (GI), as fibras insolúveis $(70,7 \%)$. A solubilidade das várias frações em meio aquoso não mostrou dependência do $\mathrm{pH}$ e variou entre $40 \%$ e $100 \%$. A fração que apresentou maior capacidade de retenção de água (CRA) foi a glicana solúvel ( $14,4 \mathrm{~g} \mathrm{H}_{2} \mathrm{O} / \mathrm{g}$ de amostra) e os maiores índices de solubilidade em água (ISA) foram os das frações glicoproteina (83,8\%) e manana (60\%). As frações glicana (GS e GI) apresentaram boas propriedades de geleificação nas concentrações de 12 e $14 \%$ de sólidos solúveis. As frações glicoproteína, manana e glicana solúvel apresentaram excelente capacidade de emulsificação (1.500 a 2.000 $\mathrm{mL}$ óleo/g amostra) e as emulsões de glicoproteína e glicana solúvel foram as mais estáveis. Adição de igual concentração (0,2\%) de ovalbumina aumentou significativamente o poder de emulsificação das frações PC e GS e contribuiu para a estabilidade das emulsões da manana e da glicoproteína (M e GP).

Palavras-chaves: propriedades funcionais, parede celular, levedura, glicoproteína, manana, glicana.
\end{abstract}

\section{SUMMARY}

FUNCTIONAL (TECHNOLOGICAL) PROPERTIES OF YEAST CELLULAR WALL OF ALCOHOLIC FERMENTATION AND ITS GLYCAN, MANNAN, AND GLYCOPROTEIN FRACTIONS. The objectives of the present work were the fractionation, the chemical characterization and the study of functional (technological) properties of the cell wall (CW) of yeast from alcohol fermentation and the subfractions glycan, mannan and glycoprotein. Fractionation was realized by the physico-chemical processes of extraction, centrifugation and spray drying; chemical characterization, by determination of centesimal composition and the functional properties through wellknown techniques. In the cellular wall (CW), predominated protein (19\%) and soluble fiber (74\%). Glycoprotein presented $35.5 \%$ protein and $56 \%$ soluble fiber. In the mannnan (M) and soluble glycan (SG), the soluble fiber (70\%) was predominant, whereas in the insoluble glycan (IG) predominated the insoluble fiber (70.7\%). Solubility of the various fractions in aqueous media ranged from $40 \%$ to $100 \%$ and was not $\mathrm{pH}$ dependent. Soluble glycan showed the highest water retention capacity $\left(14.4 \mathrm{~g} \mathrm{H}_{2} \mathrm{O} / \mathrm{g}\right.$ sample $)$ and the higher water solubility indices (WSI) were found for mannan (60\%) and for glycoprotein (83.8\%). The glycans (soluble and insoluble) presented good gelling properties at 12 and 14\% solid concentrations. Glycoprotein, mannan and soluble glycan presented excellent emulsifying capacity ( 1,500 to $2,000 \mathrm{ml}$ oil/g sample). The glycoprotein and soluble glycan emulsitions were the most stable. Addition of ovalbumin $(0.2 \%)$ in the emulsifying media increased significantly the cellular wall and soluble glycan emulsifying capacity. It also contributed for the stabilization of the mannan (M) and glycans (IG and SG) emultions.

Keywords: functional properties, cell wall, glycoprotein, mannan, glycan.

\section{1 - INTRODUÇÃO}

A funcionalidade de um ingrediente está relacionada com suas características físico-químicas mais relevantes que exercem grande influência nos processos de elaboração, estocagem, qualidade e aceitação de um alimento [9].

Na área de alimentos, muitos polissacarídeos de origem microbiana têm sido largamente utilizados como espessantes, devido à sua viscosidade em sistema aquoso. Outra aplicação de grande interesse é a sua utilização

\footnotetext{
${ }^{1}$ Recebido para publicação em 20/5/2005. Aceito para publicação em 28/4/2005 (001534)

${ }^{2}$ Departamento de Planejamento Alimentar e Nutrição da Unicamp/FEA

Caixa Postal 6121 - Campinas (SP)

${ }^{3}$ Bolsista da Fapesp

E-mail:sgab@fea.unicamp.br

*A quem a correspondência deve ser enviada
}

como substituto de gorduras em certos tipos de alimentos dietéticos, tais como coberturas de saladas, sorvetes etc., em razão de seu flavor agradável e textura suave [5].

Em relação ao uso da levedura e seus derivados em indústrias de alimentos para produção de sopas desidratadas e produtos cárneos, KOLLAR et al. [24] ressaltam a importância de algumas propriedades funcionais específicas, a saber: solubilidade, absorção de água e óleo, retenção de água e capacidade emulsificante.

A solubilidade dos ingredientes de um alimento como a sopa é muito importante, uma vez que poderá influenciar no sabor e textura do alimento. As proteínas de células isoladas de levedura possuem baixa solubilidade quando comparadas a outras proteínas vegetais como a soja, principalmente nas faixas de $\mathrm{pH}$ mais comuns nos alimentos [37].

De acordo com DE KANTEREWICZ et al. [11], a capacidade de absorção de óleo tem grande importância na formulação de alimentos, podendo influenciar na ordem 
de adição dos ingredientes secos na mistura, além de ser usado para determinar os tempos de mistura utilizando uma distribuição uniforme do óleo ou gordura na mistura seca. OTERO et al. [31] observaram que a capacidade de absorver óleo do concentrado protéico de levedura foi aproximadamente três vezes o valor da absorção de óleo do isolado protéico de soja.

A absorção de água de um componente do alimento determina não somente a aceitabilidade do produto final em termos de textura e suculência, mas também a sua margem de lucro. Estes índices são essenciais em alimentos como a gelatina, na qual se obtém um produto com aproximadamente 95\% de água [21].

De acordo com KINSELLA [23], a capacidade de retenção de água é de grande utilidade na fabricação de produtos cárneos, impedindo a perda de água no processo de cozimento, em produtos de panificação e em alimentos viscosos como sopas. De acordo com NAGODAWITHANA [30], os nucleotídeos obtidos do RNA de levedura são atualmente empregados como enriquecedores do sabor à carne ou queijo em indústria de alimentos, o que indica a necessidade de avaliação de absorção de água.

A capacidade de uma proteína de formar e estabilizar emulsões é fator crítico para a produção de carnes moídas, massas para bolos, cremes para café, maioneses, molhos para saladas e sobremesas congeladas. MARQUES et al. [28] afirmam que o uso da glicana de levedura como emulsificante se destaca por ser de origem biológica. LEE [25], ao analisar a glicana, extraída de uma fração da parede celular de levedura, avalia que a mesma poderá ser utilizada como emulsificante, estabilizante ou texturizante, além de ser útil na formulação de alimentos com baixo teor de gordura e de calorias.

Nesta pesquisa procurou-se extrair, a partir da parede celular (PC) obtida por autólise da biomassa de levedura, as frações glicanas, mananas e glicoproteínas e testá-las em relação a algumas propriedades funcionais tecnológicas importantes no processamento de alimentos.

\section{2 - MATERIAL E MÉTODOS}

\section{1 - Material}

\subsection{1 - Processo de lavagem da biomassa (levedura bruta)}

A biomassa de levedura (Saccharomyces sp.) coletada sem sofrer o processo de termólise foi recebida da usina São José, Zillo Lorenzetti (Macatuba, SP), em suspensão de aproximadamente $20 \%$ (p/v) de células. Essa suspensão foi diluída (1:1) com água e as células separadas em centrífuga contínua de pratos Alfa Laval, tipo BRPX 20739S60 (3.500g, fluxo de $150 \mathrm{Kg} / \mathrm{h}$ e descarga a cada $5 \mathrm{~min}$ ), obtendo-se um sedimento de biomassa e seu sobrenadante (água de saída), recirculado na centrífuga para recuperar as células arrastadas na água de lavagem. A biomassa foi então resuspensa em água (30\% p/v) e desidratada em spray dryer Niro Atomizer CB3 $104 \mathrm{D}$ a $180^{\circ} \pm 5^{\circ} \mathrm{C}$ na entrada da câmara e $80^{\circ} \pm 5^{\circ} \mathrm{C}$ na saída.

\section{2 - Métodos}

\subsection{1 - Autólise da biomassa desidratada e fracionamento do autolisado para obtenção da parede celular}

A levedura íntegra desidratada foi ressuspensa em água ( $10 \% \mathrm{p} / \mathrm{v}$ ) e adicionada de alguns agentes autolisantes e plasmolizantes, a saber: $15 \%(\mathrm{p} / \mathrm{p})$ de um pré-autolisado, $7 \%(\mathrm{p} / \mathrm{p})$ de etanol e $2 \%(\mathrm{p} / \mathrm{p})$ de $\mathrm{NaCl}$. A mistura ajustada ao pH 5,5 foi levada para fermentador de $250 \mathrm{~L}$ (New Brunswick - IF250), onde foi mantida à temperatura de $55^{\circ} \mathrm{C}$ por $24 \mathrm{~h}$, sob agitação mecânica. A autólise foi então interrompida por aquecimento a $85^{\circ} \mathrm{C}$ durante $15 \mathrm{~min}$. O autolisado, após secagem em spray dryer, se transformou no autolisado desidratado (AUT). Parte do autolisado foi submetida a um fracionamento por centrifugação (centrífuga de pratos - 3.500g, fluxo de $150 \mathrm{Kg} / \mathrm{h}$ e descarga a cada $5 \mathrm{~min}$ ), para obtenção da fração insolúvel (parede celular bruta).

A fração insolúvel (parede celular), obtida pela centrifugação do autolisado, foi ressuspensa em água ( $10 \%$ p/v) e em seguida desidratada em spray dryer (Niro Atomizer CB3 104D) para obtenção da parede celular bruta desidratada.

\subsection{2 - Extração da fração lipídica da parede celular desidratada}

A fração lipídica foi isolada da parede celular (desidratada) com etanol 95\% na proporção de 1:2 (p/v) (2 extrações) e n-hexano na proporção de 1:2 (p/v) (4 extrações). A combinação dos extratos obtidos com o etanol e com n-hexano foi filtrada e concentrada em rotavapor, conforme metodologia descrita por KOLLAR et al. [24]. Foram feitas algumas modificações, como: extrações com etanol 95\% (2 extrações) e n-hexano (4 extrações), utilizando rotação de $14.000 \mathrm{~g}$, durante $20 \mathrm{~min}$, à temperatura de $10^{\circ} \mathrm{C}$.

\subsubsection{Fracionamento da parede celular desengordurada}

O fracionamento da parede celular desengordurada foi realizado de acordo com OTERO et al. [31]. A fração parede celular desengordurada foi resuspensa em $\mathrm{NaOH}$ $1 \%$ na proporção (1:3), com homogeneização mecânica e aquecida a $75^{\circ} \mathrm{C}$ durante $20 \mathrm{~min}$, em banho com agitação. Após resfriamento, foi centrifugada a $13.200 \mathrm{~g}$ por $30 \mathrm{~min}$ a $5^{\circ} \mathrm{C}$. O sobrenadante foi concentrado a vácuo até $100 \mathrm{~mL}$, adicionado de $300 \mathrm{~mL}$ de etanol a $95^{\circ} \mathrm{GL}$, sob agitação e deixado $12 \mathrm{~h}$ a $4^{\circ} \mathrm{C}$, para precipitação da glicoproteína que foi então recuperada por centrifugação. A operação referente à extração da glicoproteína e demais frações está mostrada no fluxograma da Figura 1 . O resíduo remanescente (resíduo A), após a extração das glicoproteínas, foi submetido à extração com $\mathrm{KOH} 2 \%$ na proporção de $1: 2$ (uma extração) durante $3 \mathrm{~h}$ a $93^{\circ} \mathrm{C}$ com agitação. 
Posteriormente, foi submetido à centrifugação a 14.000g, $30 \mathrm{~min}$ a $5^{\circ} \mathrm{C}$ e lavado com água destilada na proporção de 1:2 para obtenção da fração glicana insolúvel. O sobrenadante da extração com KOH $2 \%$ foi tratado com três volumes de etanol 95\% sob agitação durante 30 min e levado para câmara fria durante $12 \mathrm{~h}$ a $4^{\circ} \mathrm{C}$. Após esse tempo foi homogeneizado, centrifugado a $14.000 \mathrm{~g}$ por 30 min a $5^{\circ} \mathrm{C}$ e lavado com etanol $95 \%$ na proporção de $1: 3$, para obtenção da fração manana.

\subsection{4 - Procedimento para a solubilização da fração glicana (insolúvel)}

O maior obstáculo para utilização da $\beta$-1,3-D-glicana é a sua insolubilidade em meio aquoso. A possibilidade de se preparar uma glicana solúvel, com atividade imunológica, a partir da glicana de levedura insolúvel já foi demonstrada por WILLIAMS et al. [42]. No presente estudo, a glicana insolúvel foi transformada em glicana solúvel, segundo os passos descritos no fluxograma da Figura 2.

\subsection{5 - Diálise, desidratação e cálculo do rendimento das fraçóes}

As frações obtidas em todo o processo de fracionamento, realizado em triplicata, foram dialisadas com água destilada a $4^{\circ} \mathrm{C}$, com agitação e troca de água três vezes ao dia (volume $10 \mathrm{~L}$ ) durante três dias. O objetivo da diálise foi eliminar o $\mathrm{NaCl}$ e compostos de baixo peso molecular $(\mathrm{PM}<8.000 \mathrm{Da})$. Em seguida, as amostras dialisadas foram liofilizadas ou desidratadas em spray dryer, pesadas para determinação do rendimento e armazenadas a $-18^{\circ} \mathrm{C}$ para posterior realização dos estudos programados.

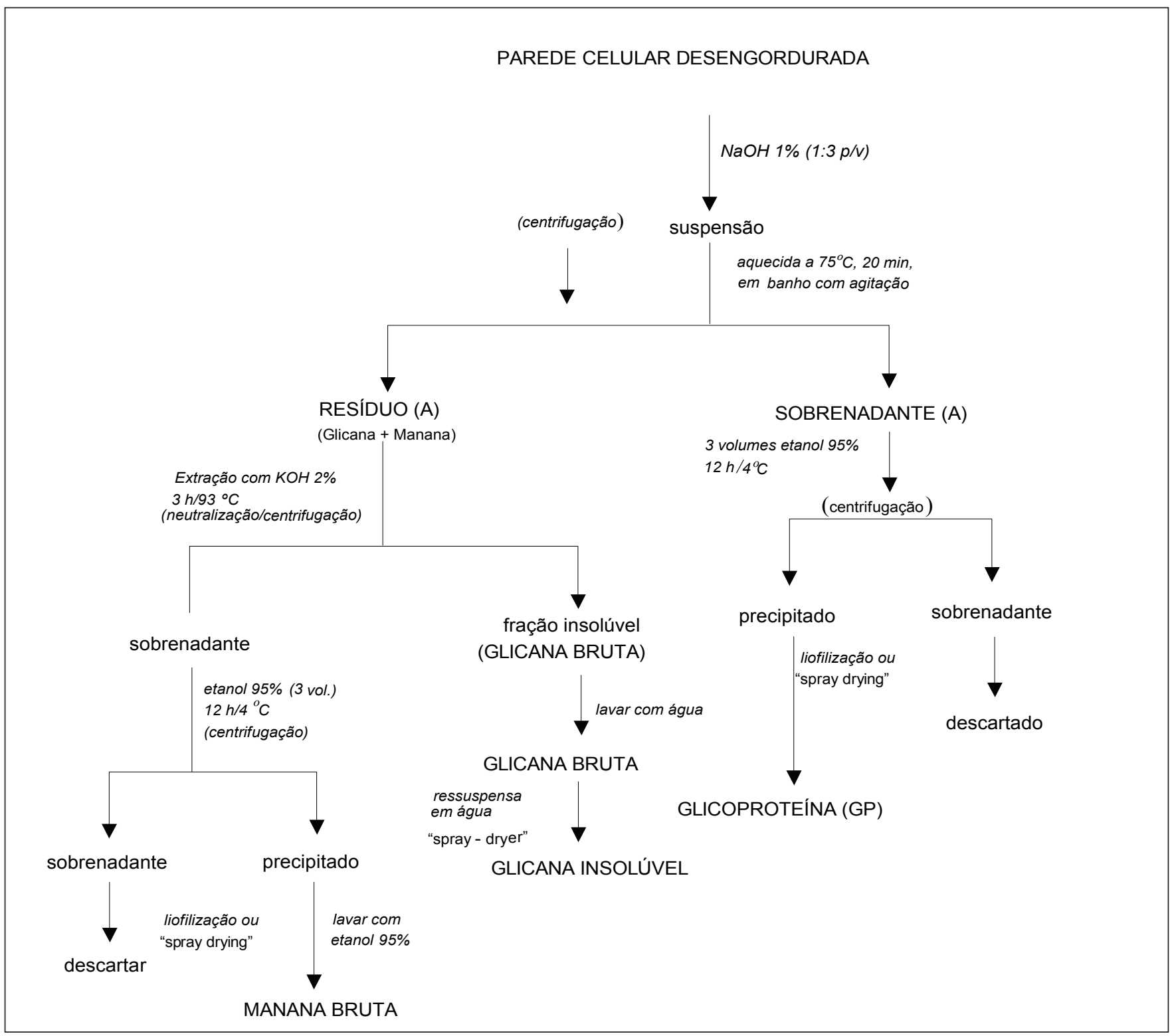

FIGURA 1 - Fluxograma de extração das frações glicoproteína, glicana insolúvel e manana, a partir da parede celular desengordurada 


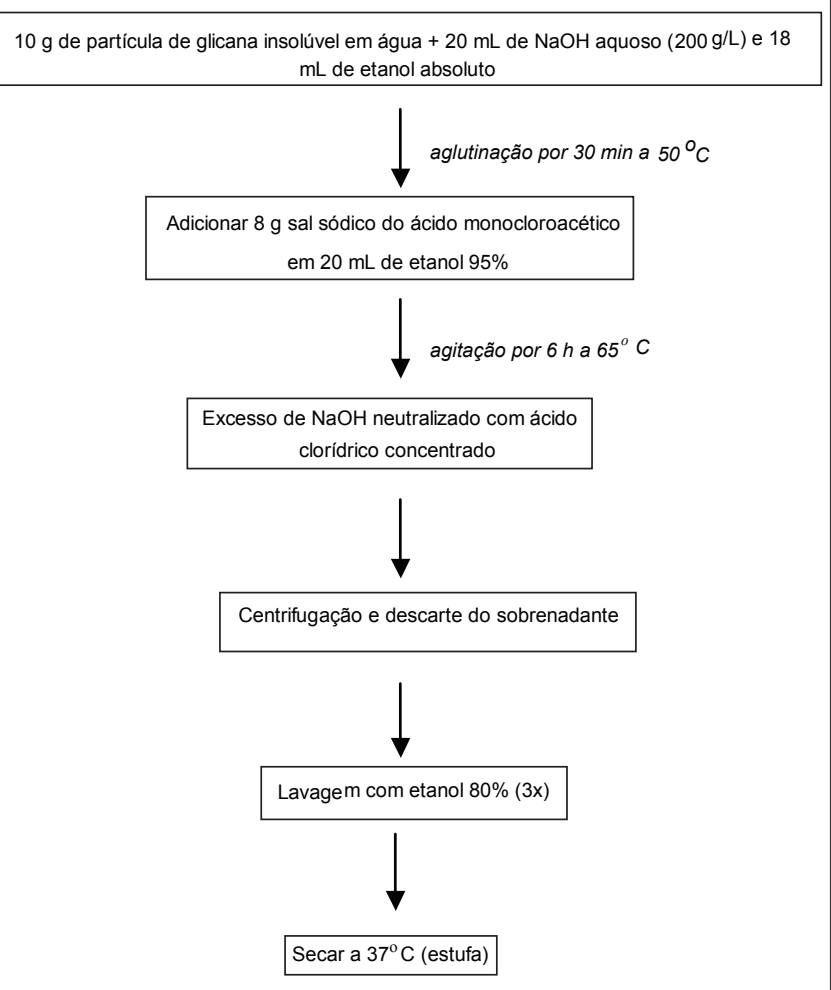

FIGURA 2 - Procedimento para a solubilização da glicana bruta [42]

\subsection{6 - Composição centesimal}

A composição centesimal da parede celular (PC) e das frações glicoproteína (GP), glicana solúvel (GS), glicana insolúvel (GI) e manana (M) foram determinadas a partir de três repetições analíticas.

Umidade e sólidos totais. Umidade e sólidos totais foram determinados segundo a AOAC [3]. Os sólidos totais foram obtidos pela diferença entre o peso total da amostra e o conteúdo em umidade, após secagem em estufa a $105^{\circ} \mathrm{C}$ até peso constante.

Cinza. O teor de cinza foi determinado de acordo com a metodologia descrita pela AOAC [3] que se baseia no resíduo que permanece após a incineração da amostra a $500-550^{\circ} \mathrm{C}$, para destruição da matéria orgânica.

Determinação da fibra (solúvel e insolúvel). Os teores de fibra solúvel e insolúvel foram obtidos por método enzimático e gravimétrico [33], no qual a amostra finalmente moída é ressuspensa e submetida primeiramente à ação de protease (Sigma $\mathrm{n}^{\circ} \mathrm{P}-3930$ ) e amiloglicosidase (Sigma n ${ }^{\circ}$ A-9913). A partir do hidrolisado assim obtido, são determinados os teores de fibra insolúvel, por lavagem em um filtro com água e acetona e de fibra solúvel a partir do filtrado por precipitação com etanol a 95\% e filtração seguida de lavagem no próprio filtro com etanol e acetona. A filtração foi realizada com auxílio de lã de vidro. Após secagem, o material foi pesado e corrigido para teores de proteína e cinza. A fibra alimentar total é estimada pela soma dos teores de fibra insolúvel e solúvel.
Nitrogênio total (proteína bruta). O teor de nitrogênio foi determinado pelo método de Kjeldahl (semi-micro) [3], que é baseado na digestão ácida da amostra, formação de amônia, destilação em meio básico e titulação com solução padrão de ácido clorídrico. Multiplicando-se o teor de N pelo fator 6,25 obtém-se o conteúdo estimado de proteína.

Lipídios totais. Os lipídios polares e apolares foram determinados gravimetricamente após extração com uma mistura dos solventes: clorofórmio, metanol e água, na proporção de 10:20:0,8 e evaporação dos solventes [6].

\subsection{7 - Solubilidade (nitrogênio e sólidos solúveis)}

As determinações foram feitas segundo o procedimento descrito por MORR et al. [29], que é uma modificação do procedimento utilizado para a obtenção do índice de solubilidade do nitrogênio. A solubilidade foi avaliada na faixa de pH de 2,0 a 12,0 em solução aquosa e salina $0,1 \mathrm{M}$, e os valores de $\mathrm{pH}$ ajustados com $\mathrm{NaOH} 0,1 \mathrm{~N}$ ou $\mathrm{HCl}$ 0,1 N. As suspensões foram deixadas em agitação por $1 \mathrm{~h}$ à temperatura ambiente, sendo o teor de proteína no sobrenadante após centrifugação determinado pelo método de Kjeldhal [3] e os sólidos solúveis, quantificados gravimetricamente após evaporação do solvente até peso constante.

\subsection{8 - Capacidade de retenção de água (C.R.A.) e índice de solubilidade em água (I.S.A.)}

Foram determinados segundo ANDERSON et al. [2]. Nesse sentido, uma mistura contendo 2,5 g das amostras e $30 \mathrm{~mL}$ de água, após mantida sob agitação por $30 \mathrm{~min}$, é centrifugada a $1.611 \mathrm{~g}$ por $15 \mathrm{~min}$ a $20^{\circ} \mathrm{C}$. O sedimento é então pesado e, no sobrenadante, determinado o resíduo seco (sólidos solúveis) após evaporação. Os índices são então calculados de acordo com as Equações (1) e (2):

Peso do resíduo de centrifugação (g)

C.R.A $=\overline{\text { Peso de amostra (b.s) (g) - Peso do resíduo de evaporação }}$

Peso do resíduo de evaporação (g) x 100

I.S.A $=$

Peso de amostra (b.s) (g)

\subsection{9 - Geleificação}

Inicialmente, foram preparadas dispersões de amostras em diferentes concentrações, para determinar a concentração mínima de amostra onde ocorre geleificação, conforme metodologia de SATHE \& SALUNKE [35], com algumas modificações. Dispersões de 2, 4, 6, 8 e 10\% foram preparadas em $10 \mathrm{~mL}$ de tampão fosfato $20 \mathrm{mM}, \mathrm{pH}$ 7,0, e colocadas em tubos de ensaio. Os tubos foram aquecidos por $1 \mathrm{~h}$ à temperatura de $90^{\circ} \mathrm{C}$, resfriados rapidamente e mantidos por $2 \mathrm{~h}$ a $4^{\circ} \mathrm{C}$. A menor concentração capaz de promover geleificação foi aquela em que os tubos foram invertidos e as amostras não caíram ou deslizaram pela parede do tubo. 


\subsubsection{0 - Textura dos géis}

As medidas de textura dos géis foram realizadas pelo método de compressão, usando o analisador de textura $\mathrm{TA}^{\mathrm{XT}} \mathrm{T}_{2}$. Os parâmetros de dureza, fraturabilidade e adesividade determinadas neste estudo correspondem ao pico de força durante a primeira compressão (programa return to start) [7].

O diâmetro da sonda foi de 1 polegada, a velocidade de $1 \mathrm{~mm} / \mathrm{min}$, em temperatura ambiente, realizando $50 \%$ de compressão. Foram escolhidas as concentrações de 12 e $14 \%$ para realizar as medidas de força do gel das amostras glicana solúvel e glicana insolúvel. Os géis para análise de textura foram preparados em tampão fosfato $20 \mathrm{mM}, \mathrm{pH}$ 7,0.

As dispersões foram pré-aquecidas por aproximadamente 3 minutos à temperatura de $40^{\circ} \mathrm{C}$, colocadas em tubos com $11 \mathrm{~mm}$ de diâmetro e desaeradas por centrifugação a $400 \mathrm{~g}$ durante $10 \mathrm{~min}$ na temperatura de $20^{\circ} \mathrm{C}$. A seguir, os tubos foram colocados em banho de água a $90^{\circ} \mathrm{C}$ por 30 min e, em seguida, resfriados rapidamente. Os géis foram cortados em pedaços de $2 \mathrm{~cm}$ de altura para as determinações no texturômetro, onde foram comprimidos em $50 \%$ de sua altura original.

\subsubsection{1 - Capacidade emulsificante (C.E.)}

Para avaliação prévia foi empregado o procedimento descrito por DE KANTEREWICZ et al. [12], combinandose dispersões de amostras a $1 \%$ e óleo de soja refinado comercial tipo 1 Tupã em volume final de $50 \mathrm{~mL}$. Após 3 min (em banho de gelo) em homogeneizador Ultra-Turrax $\mathrm{T}_{25}$, a $1.000 \mathrm{rpm}$, o óleo foi adicionado a partir de uma bureta, com homogeneização simultânea até a inversão das fases.

Como a visualização não é muito precisa, o ponto de inversão das fases foi determinado de acordo com o método descrito por DAGORN-SCAVINER et al. [10] com algumas modificações, ou seja, preparava-se primeiro a mistura de dispersões de óleo de soja em proporção próxima ao ponto de quebra determinado pelo método de DE KANTEREWICZ et al. [12], homogeneizando-se por $1 \mathrm{~min}$ a $1.000 \mathrm{rpm}$ em banho de gelo. A seguir, o óleo era adicionado gota a gota sobre a mistura em agitação até inversão das fases caracterizada pela quebra da emulsão visualizada pela mudança de coloração e separação das fases. Para melhor visualização da quebra utilizava-se sete gotas de uma solução de sudan $3(0,1 \mathrm{~g}$ de sudan $3,50 \mathrm{~mL}$ de glicerina líquida e $50 \mathrm{~mL}$ de álcool etílico $95 \%$ ). $\mathrm{O}$ resultado final foi expresso em $\mathrm{mL}$ de óleo adicionados até o ponto de inversão, por g de amostra.

\subsubsection{2 - Estabilidade da emulsão (E.E.)}

Foi determinada de acordo com a metodologia descrita por ACTON \& SAFFLE [ 1], com algumas adaptações devidas às condições do laboratório. Assim, foi tomada uma proporção da dispersão/solução no momento que ocorreu a quebra da emulsão da mesma amostra quando estava sendo feita a capacidade de emulsificação e em seguida foi coletada uma alíquota de $5 \mathrm{~mL}$ para determinação da umidade. Alíquotas de $10 \mathrm{~mL}$ foram mantidas em tubos à temperatura ambiente por $24 \mathrm{~h}$, das quais foram coletadas novas amostras, da parte inferior do tubo $(5 \mathrm{~mL})$, para determinação de umidade em triplicata (Equação 3).

E.E. $(\%)=\frac{100-U_{24 \text { horas }}^{X}}{100-U_{\text {original }}} 100$

Onde:

$\mathrm{U}_{24 \text { horas }}=$ porcentagem de umidade após $24 \mathrm{~h}$

$\mathrm{U}_{\text {original }}=$ porcentagem de umidade na emulsão recém preparada

\subsubsection{3 - Capacidade de absorção de água (C.A.A.)}

Foi determinada usando modificação do aparelho de Baumann efetuada por TORGENSEN \& TOLEDO [39]. O aparelho consiste de um funil conectado a um capilar horizontal (pipeta de 1,0 a 2,0 mL, graduada em centésimos de $\mathrm{mL}$ ). A amostra ( $1 \mathrm{~g}$ ) foi espalhada em um papel de filtro Whatman $\mathrm{n}^{\circ} 1$, umedecido, colocado no topo de um funil de Büchner com água ao nível da placa perfurada, tomando-se o cuidado de retirar o excedente de água, com papel absorvente. $\mathrm{O}$ ensaio foi conduzido à temperatura ambiente de $25^{\circ} \mathrm{C}$. A absorção de água pela amostra, ao longo de $35 \mathrm{~min}$ foi lida na pipeta, a intervalos de tempo cronometrados, e expressa em $\mathrm{mL}$ de água absorvida por $\mathrm{g}$ de amostra. As determinações foram efetuadas em triplicata, e quando necessário até em quintuplicata, devido à variabilidade intrínseca do método.

\subsubsection{4 - Capacidade de absorção de óleo (C.A.O.)}

Foi realizada no mesmo equipamento descrito para absorção de água, seguindo-se a metodologia de DE KANTEREWICZ et al. [12] empregando filtro de microfibra de vidro Whatman GF/C, e óleo de soja tipo 1 Tupã, por um período de $10 \mathrm{~min}$, a intervalos de tempo cronometrados. O resultado foi expresso em $\mathrm{mL}$ de óleo absorvido por $\mathrm{g}$ de amostra.

\subsubsection{5 - Análise estatística}

Os resultados experimentais foram comparados por ANOVA e teste de Tukey para determinação da diferença estatística entre as médias $(\mathrm{p}<0,05)$ utilizando-se o programa Statistica for Windows, versão 5.5 [38].

\section{3 - RESULTADOS E DISCUSSÃO}

\section{1 - Rendimento e composição centesimal das fraçóes da parede celular (PC) semi-purificada de levedura da fermentação alcoólica obtida pelo processo de autólise industrial}

O rendimento das frações obtidas a partir da PC submetida ao processo de autólise industrial é mostrado na Tabela 1. 
TABELA 1 - Fracionamento dos componentes da parede celular de levedura (PC) semi-purificada, obtida pelo processo de autólise industrial

\begin{tabular}{lcc}
\hline Componentes & Quantidade (g) & Rendimento (\%) \\
\hline Parede celular & $1.000,0$ & 100,0 \\
Fração lipídica & 61,8 & 6,2 \\
Glicoproteína & 94,9 & 9,5 \\
Mananas & 251,3 & 25,1 \\
Glicanas & 429,2 & 42,9 \\
Recuperação & 837,2 & 83,7 \\
\hline
\end{tabular}

As frações extraídas com maior rendimento corresponderam às mananas $25,1 \%$ e às glicanas $42,9 \%$.

A literatura traz poucas referências à quantidade e proporção de frações de polissacarídeos na parede celular de S. cerevisiae. Além disso, três aspectos se destacam: a) são referências da década de 50 e 60; b) foram analisadas células cultivadas em meio sintético de laboratório, em condições de crescimento ideais; c) os dados referem-se exclusivamente a duas frações denominadas glicana e manana.

MACWILLIAM [27] relata que as glicanas representam 30 a $45 \%$ do peso seco da parede celular da levedura de cervejaria; e as mananas representam também 30 a $45 \%$ e ainda que o valor médio para cada uma dessas frações é de $40 \%$. ROSE [34] também cita que 60 a 90\% da parede celular são compostas por polissacarídeos, apontando para a existência de glicanas e mananas em proporção praticamente igual na parede celular de S. cerevisiae e com teor total variando entre 60 e $90 \%$.

A composição centesimal da parede semi-purificada e de suas respectivas frações, objeto desta pesquisa, está apresentada na Tabela 2 . A composição é bastante semelhante à relatada na literatura por vários pesquisadores brasileiros e do exterior [ 14, 15, 22, 32]. Na fração parede celular (PC), o componente quantitativamente mais importante é a fibra (77,8\%), com grande predominância de fibra solúvel (74\%). Mesmo depois de lavada exaustivamente com água, permanece de 18 a 20\% de proteína residual, que são as glicoproteínas estruturais [8, 18, 41].

O componente quantitativamente mais importante da composição centesimal média das frações extraídas da PC semi-purificada é a fibra, com predominância de fibra solúvel $(70,34 \%)$ para as mananas, fibra insolúvel $(75,2 \%)$ para as glicanas insolúveis e fibra solúvel $(70,73 \%)$ para as glicanas solúveis.

A fração glicoproteína apresentou maior teor de proteína que as demais (35,5\%). Nas demais frações, os teores de proteínas variaram entre $6,16 \%$ e 6,12\% (glicana solúvel e insolúvel) e 5,57\% para as mananas.

Os componentes não determinados das glicanas solúveis que representam $12,72 \%$ poderão ser oligossaca- rídeos ou monossacarídeos que não foram precipitados pelo etanol 95\% durante o processo de determinação de fibra solúvel e insolúvel, além de resíduos de reagentes que foram utilizados no processo de solubilização da glicana insolúvel.

TABELA 2 - Composição centesimal da parede celular (PC) semi-purificada de levedura da fermentação alcoólica obtida pelo processo de autólise industrial e de suas respectivas frações dialisadas

\begin{tabular}{lccccc}
\hline $\begin{array}{l}\text { Componente } \\
(\% \text { b.s.) }\end{array}$ & PC & GP & M & GI & GS \\
\hline Proteína (Nx6,25) & 18,80 & 35,51 & 5,57 & 6,16 & 6,12 \\
Fibra alimentar: & 77,80 & 56,84 & 83,88 & 84,40 & 76,38 \\
Total & 3,80 & 0,64 & 13,54 & 75,20 & 5,65 \\
Insolúvel & 74,00 & 56,20 & 70,34 & 9,20 & 70,73 \\
Solúvel & 1,40 & 6,74 & 3,09 & 3,96 & 4,10 \\
Cinza & 2,00 & 0,16 & 0,55 & 4,01 & 0,68 \\
Lipídios totais & 0 & 0,75 & 6,91 & 1,47 & 12,72 \\
Não determinados & (diferença) & & & &
\end{tabular}

${ }^{1}$ Média de duas determinações

PC parede celular; GP glicoproteína; M Manana; GI- glicana insolúvel; GS glicana solúvel

\section{2 - Propriedades funcionais da parede celular (PC) semi-purificada e fraçóes da parede celular de levedura}

Cabe, inicialmente, destacar que vários fatores, como polissacarídeos, lipídios, tipo e composição de aminoácidos que compõem as amostras e os vários métodos utilizados para extração e fracionamento podem ter influenciado as propriedades funcionais da parede celular e de suas respectivas frações.

\subsection{1 - Solubilidade de nitrogênio e de sólidos totais}

Os resultados de solubilidade de nitrogênio e de sólidos solúveis totais são mostrados nas Figuras 3 e 4 . Ao se observar os dados de solubilidade da PC semi-purificada e das frações da parede celular de levedura da fermentação alcoólica, observa-se pouca ou nenhuma dependência do $\mathrm{pH}$, sugerindo que o nitrogênio se encontra em forma não protéica ou formando complexos solúveis com outros materiais da parede celular na faixa de $\mathrm{pH}$ estudada. Apenas a fração glicana insolúvel apresentou variações na solubilidade do nitrogênio, em função do pH. A glicana solúvel foi a fração que apresentou maior solubilidade de nitrogênio em todos os valores de $\mathrm{pH}$, seguida da fração glicoproteína e da fração manana (Figura 3).

Os resultados de solubilidade em relação à porcentagem de sólidos solúveis mostraram que a fração glicana solúvel foi o que apresentou maior solubilidade e a fração glicana insolúvel menor solubilidade como era de se esperar (Figura 4). Da mesma forma que para o nitrogênio a solubilidade dos sólidos totais não 
apresentou dependência do pH, com exceção da glicana insolúvel, com alguma elevação de solubilidade entre pH 5,0 e 8,0.

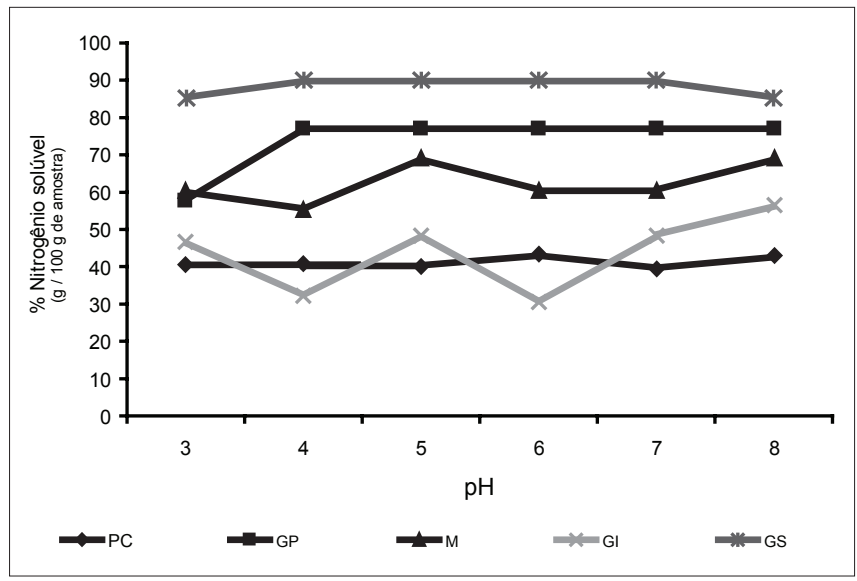

FIGURA 3 - Perfil de solubilidade de nitrogênio da parede celular (PC) semi-purificada e das frações de parede celular de levedura da fermentação alcoólica obtida pelo processo de autólise industrial. PC - parede celular, GP - glicoproteína, M - manana, GI - glicana insolúvel, GS - glicana solúvel

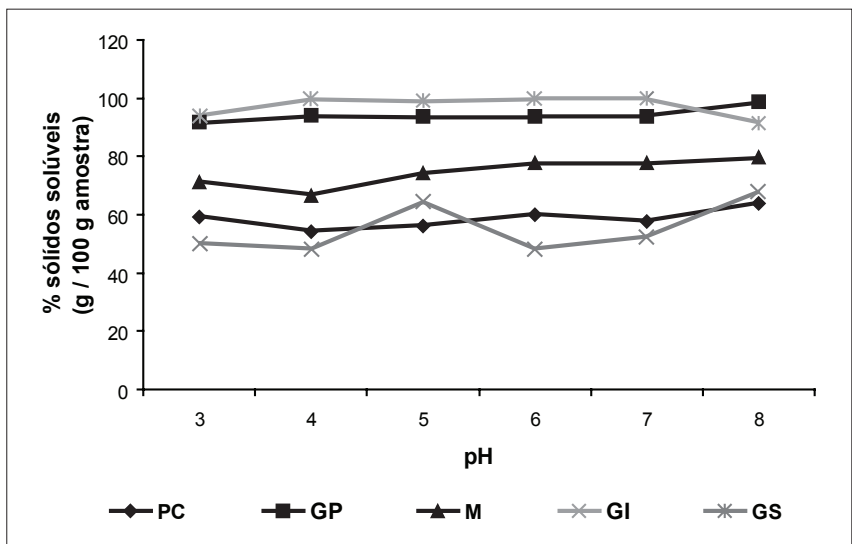

FIGURA 4 - Perfil de solubilidade para sólidos solúveis na parede celular (PC) semi-purificada e nas frações da parede celular de levedura da fermentação alcoólica obtida pelo processo de autólise industrial. PC - parede celular, GP - glicoproteína, M - manana, GI - glicana insolúvel, GS - glicana solúvel

Observa-se que a mesma ordem de solubilidade encontrada para o nitrogênio é também observada nos sólidos totais em relação à $\mathrm{PC}$ e suas frações. A parede celular e a glicana insolúvel apresentam a menor solubilidade, glicana solúvel e glicoproteína as mais altas solubilidades (próximo de $100 \%$ ) e a fração manana, solubilidade intermediária, ao redor de $80 \%$.

\subsection{2 - Capacidade de absorção de água}

A Figura 5 mostra o perfil de absorção de água pela parede celular (PC) e suas respectivas frações. A fração glicana solúvel, seguida da fração glicana insolúvel, foram

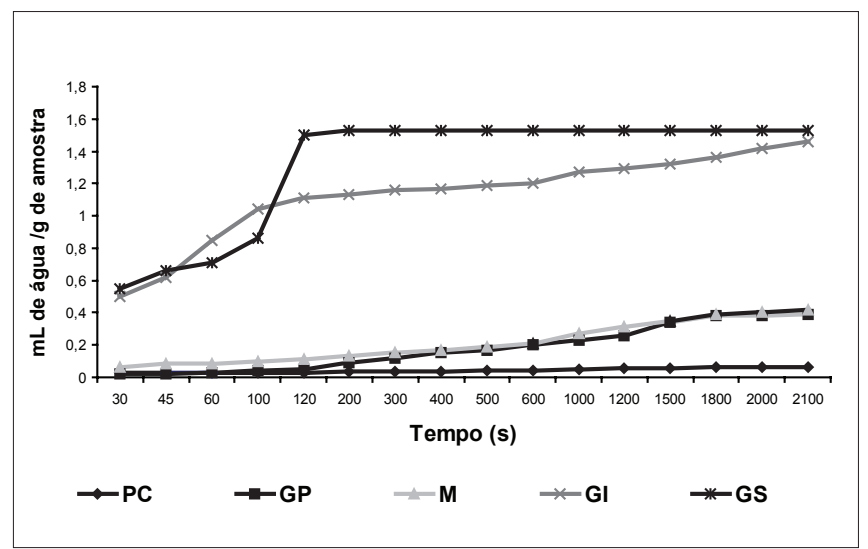

FIGURA 5 - Capacidade de absorção de água pela parede celular (PC) semi-purificada e pelas frações da parede celular de levedura da fermentação alcoólica obtida pelo processo de autólise industrial. PC - parede celular, GP - glicoproteína, M - manana, GI - glicana insolúvel, GS - glicana solúvel

as que apresentaram os maiores valores de absorção de água, confirmados por grande número de repetições. Verifica-se que a diferença do menor para o maior valor para absorção de água, 0,03 parede celular para 1,53 glicana solúvel ( $\mathrm{mL}$ de água/g amostra) foi significativa, mostrando existir uma atração hidrofílica bastante forte que é medida pelo grau de hidratação (g de água/g de amostra) da fração glicana solúvel e glicana insolúvel.

Observou-se também que a fração glicana solúvel absorveu água rapidamente e depois se estabilizou, provavelmente devido ao fato de sua estrutura ter maior facilidade em capturar água formando um gel (rede tridimensional). A parede celular e as frações glicoproteína e manana foram as que apresentaram menor atração hidrofílica, provavelmente por apresentarem em sua superfície menor densidade de grupos hidrofílicos.

Em relação à capacidade de absorção de óleo, constatou-se o inverso. A fração glicoproteína que apresentou pouca atração hidrofílica teve uma elevada atração lipofílica, provavelmente relacionada com seu caráter superficial hidrofóbico e a glicana insolúvel apresentou comportamento hidrofílico/hidrofóbico semelhante sugerindo um certo balanço entre grupos hidrofílicos e hidrofóbicos superficiais.

As frações PC e glicana solúvel apresentaram baixíssima absorção de óleo. A parede celular, provavelmente devido a sua baixa solubilidade e baixa densidade de grupos hidrofílicos superficiais, e a glicana solúvel, pela sua altíssima hidrofilicidade, não apresentam nenhuma afinidade pelo óleo. A fração manana apresentou afinidade intermediária pelo óleo e pela água (melhor balanço hidrofílico/hidrofóbico) confirmando propriedade já reconhecida de excelente bioemulsificante [8].

Os tratamentos empregados para extrair ou fracionar e também as diferentes estruturas das amostras analisadas podem ter influenciado a absorção de água e de óleo. 


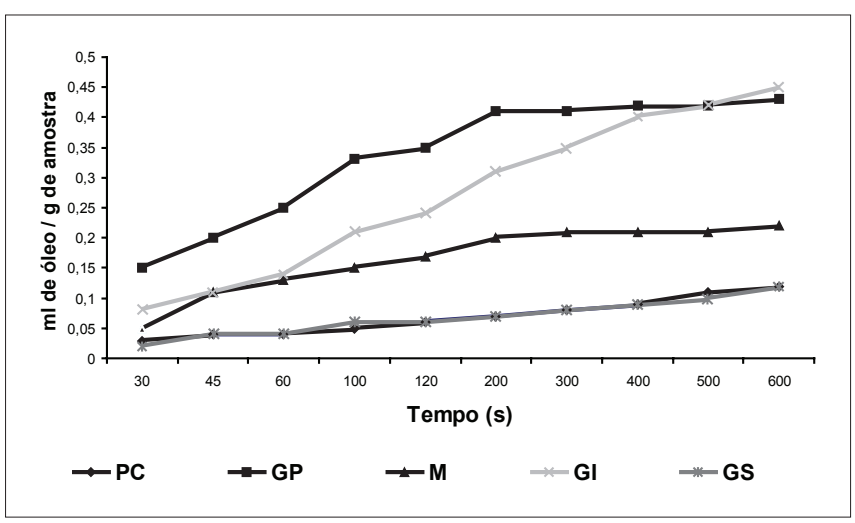

FIGURA 6 - Capacidade de absorção de óleo pela parede celular semi-purificada e pelas frações da parede celular de levedura da fermentação alcoólica obtida pelo processo de autólise industrial. PC - parede celular, GP - glicoproteína, M - manana, GI - glicana insolúvel, GS - glicana solúvel

\subsection{3 - Capacidade de retenção de água (C.R.A.) e índice de solubilidade em água (I.S.A.)}

A fração glicana solúvel que apresentou a maior capacidade de reter água (14,36 g de água/g de amostra), foi a que teve o menor índice de solubilidade em água (0,06\%). Isto se deve provavelmente ao fato da fração glicana solúvel quando diluída em água formar um gel (tridimensional) capaz de reter sólidos solúveis (Tabela 3).

A capacidade de retenção de água da fração glicana insolúvel foi inferior a das demais amostras (1,66 g de água/g de amostra), já que sua estrutura apresenta baixa capacidade de se ligar à água, formando, assim, uma rede de proteção. A fração glicoproteína, apesar de apresentar baixa capacidade de retenção de água, apresentou o maior índice de solubilidade em água, pelo fato de ser facilmente hidratada (solúvel) em água.

KINSELLA [23] observou que a retenção de água pode ser afetada por outras propriedades, como a solubilidade e a viscosidade, o que deve ser também considerado aqui.

TABELA 3 - Capacidade de retenção de água (g de água/g de amostra) e índice de solubilidade em água na parede celular (PC) semipurificada e frações da parede celular de levedura da fermentação alcoólica obtida pelo processo de autólise industrial: relação sólido-líquido (S/L) 2,5 g:30 mL de água

\begin{tabular}{lcc}
\hline Amostra* & $\begin{array}{c}\text { C.R.A } \\
\text { (g de água/g de } \\
\text { amostra) }\end{array}$ & I.S.A. (\%) \\
\hline Parede celular & $4,60 \pm 0,15^{\mathrm{c}}$ & $1,87 \pm 0,015^{\mathrm{c}}$ \\
Glicoproteína & $5,33 \pm 0,01^{\mathrm{c}}$ & $83,83 \pm 0.015^{\mathrm{a}}$ \\
Mananas & $9,83 \pm 0,01^{\mathrm{b}}$ & $60,15 \pm 0,01^{\mathrm{b}}$ \\
Glicana insolúvel & $1,66 \pm 0,015^{\mathrm{d}}$ & $1,26 \pm 0,015^{\mathrm{c}}$ \\
Glicana solúvel & $14,36 \pm 0,01^{\mathrm{a}}$ & $0,06 \pm 0,015^{\mathrm{c}}$
\end{tabular}

*Os resultados (média \pm desvio padrão de três determinações) seguidos de mesma letra (coluna) não diferem ao nível de $5 \%(p>0,05)$, avaliação estatística através do teste de Tukey

C.R.A. - capacidade de retenção de água; I.S.A. - índice de solubilidade em água

\subsection{4 - Geleificação: parâmetro de textura}

A quantidade mínima necessária para formação de géis varia de acordo com a natureza do agente geleificante, sendo necessário que o agente apresente solubilidade para interagir com o solvente e capacidade de reter água na matriz tridimensional das macromoléculas [4].

Para a fração glicana insolúvel, foi necessária concentração de 6\% para formar gel, e para fração glicana solúvel, a concentração de 3,5\% já foi suficiente para a geleificação, sendo que nestas concentrações, invertendo-se os tubos, os géis formados não desmanchavam, nem escorriam pelas paredes dos tubos. No entanto, uma vez retirados do tubo, os géis fracos de $3,5 \%$ (glicana solúvel) e $4 \%$ (glicana insolúvel) não apresentaram consistência suficiente para manterem-se firmes.

No presente estudo, os testes de avaliação de textura utilizaram géis preparados com 12 e 14\% das frações glicana solúvel e insolúvel. Como estas frações apresentam apenas $6 \%$ de proteína, capacidade de retenção de água muito grande e absorção de água bastante rápida e elevada, as dispersões a 12 e $14 \%$ formavam uma pasta muito espessa, de difícil homogeneização e manipulação para serem colocadas nos tubos de testes. Para contornar essa dificuldade, as dispersões ainda no béquer, foram aquecidas em banho de água a $40^{\circ} \mathrm{C}$ e desta maneira tornaram-se mais fluidas, permitiram melhor homogeneização e escoamento para dentro dos tubos.

Os parâmetros de textura dos géis formados com 12 e $14 \%$ de amostra encontram-se na Tabela 4 . De acordo com BOURNE [7], a fraturabilidade, corresponde à resistência oferecida pelo gel até o momento de ruptura, a dureza corresponde à resistência do gel à compressão a uma dada profundidade, e a adesividade representa o trabalho necessário para remover a sonda compressora da amostra após a compressão.

Os melhores resultados foram observados na fração glicana insolúvel ( 12 e 14\%) que apresentou os melhores parâmetros de dureza, ou seja, uma melhor resistência do gel à compressão em uma dada profundidade. Em relação à fraturabilidade foram constatados resultados semelhantes para ambas frações nas concentrações analisadas, demonstrando uma boa resistência à penetração da sonda, devido à consistência firme dos géis formados, refletindo posteriormente na menor adesividade, ou seja, pouca aderência do gel à sonda, necessitando de menor esforço para a sonda retornar a posição inicial.

TABELA 4 - Parâmetro de textura para as frações glicana solúvel e insolúvel em diferentes concentrações

\begin{tabular}{lcccc}
\hline Parâmetro* & GS12\% & GS14\% & GI 12\% & GI 14\% \\
\hline Dureza & $17,02 \pm 0,34^{\mathrm{d}}$ & $28,16 \pm 2,86^{\mathrm{c}}$ & $34,96 \pm 3,24^{\mathrm{b}}$ & $45,02 \pm 2,46^{\mathrm{a}}$ \\
Fraturabilidade & $2,67 \pm 0,96^{\mathrm{b}}$ & $3,59 \pm 1,33^{\mathrm{a}}$ & $3,12 \pm 0,62$ a,b & $3,96 \pm 0,26^{\mathrm{a}}$ \\
Adesividade & $-2,38 \pm 1,51^{\mathrm{c}}$ & $0,43 \pm 0,12^{\mathrm{b}}$ & $-4,13 \pm 1,76^{\mathrm{a}}$ & $-6,19 \pm 1,19^{\mathrm{a}}$
\end{tabular}

*Os resultados (média \pm desvio padrão de três determinações) seguidos de mesma letra minúscula (linhas) não diferem no nível de $5 \%(p>0,05)$, avaliação estatística através do teste de Tukey GS - glicana solúvel; GI- glicana insolúvel 
No caso da parede celular e das frações, glicoproteína e manana, não houve formação de géis em nenhuma das concentrações testadas nas mesmas condições, observandose uma separação de fases durante o período de transição de prógel para gel, no resfriamento.

Baseado nos resultados obtidos da alta capacidade de retenção de água, onde evidenciou-se a presença marcante de interações do tipo agente geleificante-água, poder-se-ia supor como mecanismos de geleificação das amostras a imobilização de água por adsorção. Este mecanismo, contudo, talvez não seja o único responsável pela geleificação, mas provavelmente exerce um efeito predominante, pois algumas amostras da fração parede celular e a própria PC não formaram géis nas condições do teste.

Segundo SGARBIERI [37], a teoria de adsorção de solvente fundamenta-se na ocorrência de um aumento do volume das moléculas por adsorção de água durante o resfriamento que acabam se tocando ou sobrepondo de tal maneira que todo o sistema (solvente/soluto) torna-se imobilizado e rijo. Provavelmente, o inchamento e sobreposição das moléculas do agente geleificante tenha viabilizado a formação de uma estrutura ordenada, com interações intermoleculares que reforçaram a estrutura do gel, durante o resfriamento.

FIORA et al. [17] observaram a existência de correlação positiva da dureza e fraturabilidade do gel com a capacidade de absorção e retenção de água. Concluíram, no entanto, que embora o mecanismo de geleificação possa estar baseado na imobilização de água por adsorção, deve existir, adicionalmente, a formação de uma rede tridimensional através da desnaturação de proteínas e formação de ligações cruzadas.

Em géis de isolado protéico de soja (IPS) a 20\% de concentração, FURUKAWA \& OTHA [19] observaram também uma correlação positiva da formação de géis com a capacidade de retenção de água.

\subsection{5 - Propriedades emulsificantes}

Os valores da capacidade emulsificante (C.E.) e estabilidade da emulsão (E.E.) encontram-se na Figura 7 (A, B). A quantidade máxima de óleo que pode ser emulsificada (mL de óleo/g de amostra) pela dispersão em água de $0,2 \%$ de amostra foi da glicoproteína, que se mostrou superior às demais amostras, enquanto a da parede celular foi inferior a de todas as amostras. As diferenças na capacidade emulsificante poderiam ser atribuídas a diferenças na composição das amostras, alterações provocadas pelo método de extração na estrutura conformacional das moléculas e mudanças na solubilidade e nas características lipofílicas e hidrofílicas, que conseqüentemente interferem no comportamento interfacial do agente emulsificante (Figura 7A).

A capacidade de emulsificação das frações glicoproteína e manana não aumentou mediante a adição de $0,2 \%$ de ovalbumina à mistura emulsificante, o que comprova a excelente capacidade emulsificante $(\sim 2.000 \mathrm{~mL}$ óleo/g amostra) dessas duas frações. A parede celular (PC)

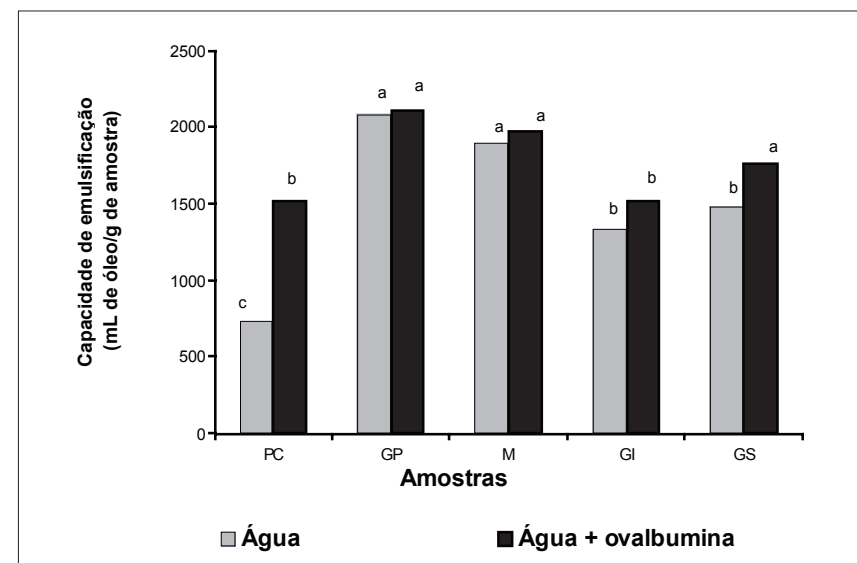

(A)

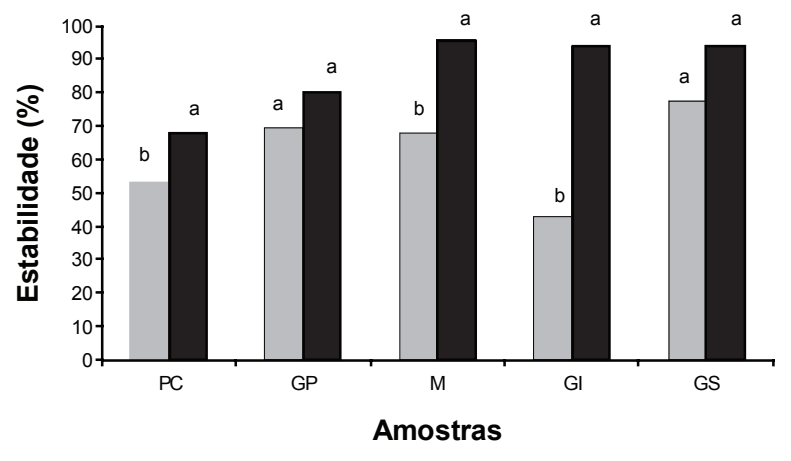

$\square$ Água

口Água + ovalbumina

(B)

*Resultados são média \pm desvio padrão de três determinações. Colunas com letras diferentes indicam diferença estatística $(p<0,05)$ pelo teste de Tukey

FIGURA 7 (A) (B) - Representação gráfica da capacidade emulsificante (A) e da estabilidade das emulsões (B) da parede celular (PC) e das frações glicoproteína (GP), manana (M), glicana insolúvel (GI) e glicana solúvel (GS), em suspensões aquosas de $0,2 \%$ de amostra ou $0,2 \%$ de amostra mais $0,2 \%$ de ovalbumina

e a glicana solúvel mostraram aumento significativo da capacidade de emulsificação com a adição de igual concentração de ovalbumina. A C.E. da glicana insolúvel (GI) embora tenha melhorado com a adição de ovalbumina, a diferença observada não foi significativa ( $p>0,05)$.

De acordo com DICKSON \& STAINSBY [13], as modificações químicas geralmente ajudam a aumentar a carga líquida negativa da proteína, ocasionando mudança na estrutura e na hidrofobicidade da molécula, afetando assim sua atividade de superfície. Em preparação da levedura Candida utilis, foram encontrados os valores de C.E. variando de 1.213,8 a 1.540,1 mL óleo/g de proteína e a estabilidade da emulsão obtida por aquecimento a $95^{\circ} \mathrm{C} / 30$ min entre $79,1 \%$ a $87,5 \%$, de acordo com o procedimento de preparo dos concentrados [36]. Para dispersões a 5\% de proteína de soja, GENOVESE \& LAJOLO [20] encontraram o valor de 1.143 g de óleo/g de proteína para a capacidade emulsificante. 
Nesta pesquisa, a emulsão preparada com a fração glicana solúvel foi a que mostrou maior estabilidade e a fração glicana insolúvel, o que apresentou a menor estabilidade (Figura 7B). Em geral, emulsificantes de diferentes origens variam bastante em sua habilidade de estabilizar emulsões, refletindo diferenças na composição e propriedades estruturais.

Verificou-se, contudo, que a estabilidade da emulsão foi melhorada em todas as frações com a adição de ovalbumina às preparações, com diferença significativa para $\mathrm{PC}, \mathrm{M}$ e GI. Os resultados foram concordantes com ELIZALDE et al. [16], que encontraram uma correlação significativa entre o aumento da concentração de proteína e de óleo, com a estabilidade da emulsão. De acordo com LEMAN \& KINSELLA [26], as proteínas formam uma película viscoelástica ao redor das gotículas de gordura, aumentando a pressão superficial e reduzindo a tensão interfacial no sentido de prevenir a coalescência. O aumento da concentração de proteína facilita a adsorção de maior número de proteínas nos glóbulos de gordura, resultando em um aumento da estabilidade da emulsão.

Acréscimo de ovalbumina $(0,2 \%)$ à suspensão de parede celular (PC) semipurificada e às suas respectivas frações, provocou um aumento significativo e estabilidade da emulsão (\%), após repouso de $24 \mathrm{~h}$, o que sugere a possibilidade de uso da parede celular (PC) e suas respectivas frações como agente flavorizante e estabilizante, em emulsões do tipo óleo/água. VILELA [40] verificou um aumento do volume de óleo, necessário para que ocorresse a quebra da emulsão ao adicionar amostras de levedura à solução de ovalbumina $0,2 \%$.

Devido ao fato da parede celular (PC) e suas respectivas frações conterem pequenas quantidades de proteína, o cálculo da capacidade de emulsificação e da estabilidade da emulsão é expresso por grama de amostra e não por grama de proteína.

\section{4 - CONCLUSÕES}

A parede celular da levedura de fermentação alcoólica industrial e suas frações glicana, manana e glicoproteína revelaram-se excelentes fontes de fibra alimentar (solúvel e insolúvel) com diferentes níveis de solubilidade em soluções aquosas e pouco sensíveis às variações de $\mathrm{pH}$. As glicanas (solúvel e insolúvel) apresentaram elevados índices de absorção de água enquanto as glicoproteínas e a glicana insolúvel apresentaram elevada absorção de óleo. A glicana solúvel apresentou a maior capacidade de retenção de água enquanto a glicoproteína e a manana apresentaram elevados índices de solubilidade em água. As frações glicana solúvel e insolúvel apresentaram boas propriedades geleificantes nas concentrações de 12 e 14\% $(\mathrm{p} / \mathrm{v})$ e as frações glicoproteína e manana apresentaram excelentes propriedades emulsificantes.

Os resultados obtidos permitem concluir que a parede celular de levedura, semipurificada, e suas frações (glicana, manana e glicoproteína) poderão encontrar várias aplicações na formulação e melhoria de propriedades funcionais de várias linhas de produtos da indústria de alimentos.

\section{5 - REFERÊNCIAS BIBLIOGRÁFICAS}

[1] ACTON, J.C.; SAFFLE, R.L. Stability of oil-in-water emulsion. 1. Effects of surface tension, level of oil, viscosity and type of meat protein. Journal of Food Science, Chicago, v. 35, n. 6, p. 852-855, 1970.

[2] ANDERSON, R.A.; CONWAY, H.F.; PFEIFER, U.F.; GRIFFIN JR., E.L. Gelatination of corn grits by roll and extrusion cooking. Cereal Science Today, St. Paul, Minnesota, v. 14, n. 1, p. 4-7, 11-12, 1969.

[3] A.O.A.C. Association of Official Agricultural Chemists, official methods of analysis. HORWITZ, W. (ed.), $17^{\text {th }}$ ed., Gaithersburg, Maryland, 2000.

[4] ARMSTRONG, H.J.; HILL, S.E.; SCHROOYEN, P.; MITCHEL, J.R.A comparison of the viscoelastic properties of conventional and maillard protein gels. Journal of Texture Studies, Westport, v. 25, n. 3, p. 285-298, 1994.

[5] BELEM, M.A.; LEE, B.H. Production of bioingredients from Kluyveromyces marxianus on Whey: an alternative. Critical Review in Food Science and Nutrition, Boca Raton, v. 38, n. 7, p. 565-598, 1998.

[6] BLIGH, E.G.; DYER, W.J. A rapid method of total lipid extraction and purification. Canadian Journal of Biochemistry and Physiology, Ottawa, v. 37, n. 8, p. 911-917, 1959.

[7] BOURNE, M.C. Texture profile analysis. Food Technology, Chicago, v. 32, n. 7, p. 62-72, 1978.

[8] CAMERON, D.R.; COOPER, D.G.; NEUFELD, R.J. The mannoprotein of Saccharomyces cerevisiae is an effective bioemulsifier. Applied and Environmental Microbiology, Washington, v. 54, n. 6, p. 1.420-1.425, 1988.

[9] CHOU, D.H.; MORR, C. V. Protein water interactions and functional properties. Journal of American Oil Chemists Society, Champaign, v. 56, n. 1, p. 53a62a, 1979.

[10] DAGORN-SCAVINER, C.; GUEGUEN. J.; LEFEB-VRE, J. Emulsifying properties of pea globulin as related to their adsorption behaviors. Journal of Food Science, Chicago, v. 2, n. 2, p. 335-341, 1987.

[11] DE KANTEREWICZ, R.J.; PILOSOF, A.M.R.; BARTHOLOMAI, G.B. A simple method for determining oil absorption capacity of protein and the kinetics of oil uptake. Journal of American Oil Chemists Society, Champaign, v. 66, n. 6, p. 809-812, 1989.

[12] DE KANTEREWICZ, R.; ELIZALDE, B.E.; PILOSOF, A.M.R.; BARTHOLOMAI, G.B. Water-oil absorption index (WOAI): a simple method for predicting the emulsifying capacity of food proteins. Journal of Food Science, Chicago, v. 52, n. 5, p. 1.381-1.383, 1987.

[13] DICKSON, E.; STAINSBY, G. Progress in formulation of food emulsions and foams. Food Technology, Chicago, v. 41, n. 9, p. 74-81, 1987.

[14] DZIEZAK, J.D. (ed.). Yeasts and yeast derivatives: definitions, characteristics, and processing. Food Technology, Chicago, v. 41, n. 2, p. 104-112, 119-120, 1987a.

[15] DZIEZAK, J.D. (ed.). Yeasts and yeast derivatives: definitions, characteristics, and processing. Food Technology, Chicago, v. 41, n. 2, p. 122-125, $1987 \mathrm{~b}$. 
[16] ELIZALDE, B.E.; PILOSOF, A.M.R.; BARTHOLOMAI, G.B. Prescription of emulsion instability from emulsion compostion and physicochemical properties of proteins. Journal of Food Science, Chicago, v. 56, n. 1, p. 116-120, 1991.

[17] FIORA, F.A.; PILOSOF, A.M.R.; BARTHOLOMAY, G.B. Physiochemical properties of soybean proteins related to flow, viscoelastic, mechanical, and water-holding characteristics of gels. Journal of Food Science, Chicago, v. 55, n. 1, p. 133-136, 1990.

[18] FLEET, G.H.; MANNERS, D.J. The enzymic degradation of an alkali-soluble glucan from the cell walls of Saccharomyces cerevisiae. Journal of General Microbiology, London, v. 98, p. 315-327, 1977.

[19] FURUKAWA, T.; OTHA, S. Mechanical and Water-holding properties of heat-induced soy proteins cels as related to their structural aspects. Journal of Texture Studies, Westport, v. 13, n. 1, p. 59-69, 1992.

[20] GENOVESE, M.I.; LAJOLO, F.M. Composition and structural characteristics of isolated soy proteins from broken and damaged seeds. Journal of Food Science, Chicago, v.58, n.1, p. 148-157, 1993.

[21] HALL, G.M. Methods of Testing Protein Functionality. Blackie academic \& professional. London, 1996, 265 p.

[22] KIHLBERG, R. The microbe as a source of food. Annual Review of Microbiology, Palo Alto, v. 26, p. 426-465, 1972.

[23] KINSELLA, J.E. Functional properties in foods; a survey. CRC Critical Reviews in Food Science and Nutrition, Boca Raton, v. 7, n. 3, p. 219-280, 1976.

[24] KOLLAR, R.; STURKIK, E.; SAJBIDOR, J. Complete fractionation of Saccharomyces cerevisiae biomass. Food Biotechnology, New York, v. 6, n. 3, p. 225237, 1992.

[25] LEE, H.O. Fundamentals of Food Biotechnology. Ed. V.C.H. Publishers Inc. New York, 1996, 431 p.

[26] LEMAN, J.; KINSELLA, J.E. Surface activity, film formation, and emulsifying properties of milk proteins. CRC Critical Reviews in Food Science and Nutrition, Boca Raton, v. 28, n. 2, p. 115-138, 1989.

[27] MACWILLIAM, I.C. The structure, synthesis and functions of the yeast cell wall - A review. Journal of the Institute of Brewing, London, v. 76, n. 6, p. 524-535, 1970.

[28] MARQUES, A.; OETTERER, M.; HORII, J. Caracterização da levedura e seu uso na alimentação. Boletim da Sociedade Brasileira de Ciência e Tecnologia de Alimentos, Campinas, v. 32, n. 1, p. 89-98, 1998.

[29] MORR, C.V; GERMAN, B.; KINSELLA, J.E.; REGENSTEIN, J.M.; VAN BUREN, J.P; KILARA, A.; LEWIS, B.A.; MANGINO, M.E. A collaborative study to develop a standardized food protein solubility procedure. Journal of Food Science, Chicago, v. 50, n. 6, p. 1.715-1.718, 1985.

[30] NAGODAWITHANA, T.W. Yeast-derived flavor and flavor enhances and their probable mode of action. Food Technology, Chicago, v. 46, n. 11, p. 138-144, 1992.

[31] OTERO, M.A.; VASALLO, M.C.; VERDIEIA, O.; FERNANDEZ, V.; BETANCOURT, D. A process for the complete fractionation of baker's yeast. Journal of
Chemistry Technology and Biotechnology, London, v. 67, n. 1, p. 67-71, 1996.

[32] PACHECO, M.T.B.; CABALLERO-CÓRDOBA, G.M.; SGARBIERI, V.C. Composition and nutritive value of yeast biomass and yeast protein concentrates. Journal of Nutritional Scinces and Vitaminology, Tokyo, v. 43, n. 6, p. 601-612, 1997.

[33] PROSKY, L; ASP, N.; SCHWEIZER, T.F.; DEVRIES, J.W.; FURDA, I. Determination of insoluble, soluble and total dietary fiber in foods and food products: interlaboratory study. Journal Association of Official Analytical Chemists, Gaithersburg, v. 71, n. 5, p. 1.017-1.023, 1988.

[34] ROSE, A.H. Composition of the envelope layer of Saccharomyces cerevisiae in relation to floculation and ethanol tolerance. Journal of Applied Bacteriology. Symposium Supplement, Oxford, v. 74, supp. 22, p. 1.105-1.185, 1993.

[35] SATHE, S.K.; SALUNKHE, D.K. Functional properties of the great northern bean (Phaseolus vulgaris, L.). Proteins: emulsion, foaming, viscosity and gelation properties. Journal of Food Science, Chicago, v. 46, n. 1, p. 71-74, 1981.

[36] SCHACHTEL, A.P. Effects of preparative process on the composition and functional properties of protein preparation from Candida utilis. Journal of Food Science, Chicago, v. 46, n. 2, p. 377-382, 1981.

[37] SGARBIERI, V.C. Proteínas em Alimentos Protéicos: Propriedades, Degradações, Modificações. São Paulo: Livraria Varela, 1996, 517 p.

[38] STATSOFT Inc. Statistica for Windows, versão 5.5. Tulsa, 1998.

[39] TORGENSEN, H.; TOLEDO, R.T. Physical properties of protein preparations related to their functional characteristics in comminuted meat systems. Journal of Food Science, Chicago, v. 42, n. 6, p. 1.615-1.620, 1977.

[40] VILELA, E.S.D. Obtenção e caracterização de derivados da biomassa de levedura (Saccharomyces sp.): propriedades nutricionais e funcionais. Tese de mestrado. Universidade Estadual de Campinas, Campinas, 142 p., 2000.

[41] VUKOVIC, R; HUNDINA-DOM LADO VEC, M.; MRSA, V. Structure of the Saccharomyces cerevisiae cell wall. Croatica Chemica Acta, Zagreb, v. 68, n. 3, p. 597605, 1995.

[42] WILLIAMS, D.L.; PRETUS, H.A.; McNAMEE, R.B.; JONES, E.L.; ENSLEY, H.E.; BRONDER, I.W.; DI LUZIO, N.R. A method for the solubilization of a $(1 \rightarrow 3)$-beta-D-glucan isolated from Saccharomyces cerevisiae. Carbohydrate Research, v. 219, p. 203213, 1991 .

\section{6 - AGRADECIMENTOS}

À Fapesp, pelo suporte financeiro, pela bolsa de doutorado e taxa de bancada concedidos. À Coopersucar, pelo fornecimento da levedura utilizada neste estudo e pelo apoio técnico e financeiro. 